\title{
Ласло Деже - дослідник української діалектології
}

\author{
ЄЛИЗАВЕТА БАРАНЬ \\ II. Rákóczi Ferenc Kárpátaljai Magyar Főiskola, UA-90202 Beregszász, Kossuth tér 6. \\ E-mail: barany.erzsebet75@gmail.com
}

(Received: 23 October 2016; accepted: 21 November 2016)

\begin{abstract}
The aim of this paper is to present László Dezső's achievements in the field of Ukrainian linguistics and historical dialectology as well as to show the importance of his research in the development of Ukrainian studies.

Keywords: László Dezső, Ukrainian language, Ukrainian studies, historical dialectology, Transcarpathian dialects
\end{abstract}

16 серпня 2016 року відійшов у вічність відомий угорський мовознавецьславіст, україніст, фахівець 3 типологічного мовознавства та ареальної лінгвістики, дослідник історії української та сербської мов.

Маємо на меті представити здобутки Ласло Деже в галузі українського мовознавства, у тому числі й історичної діалектології, вказати їх значення у розвиткові україністики загалом. Відомо, що чимало досвідчених україністів в Україні ознайомлені з діяльністю Ласло Деже, підтримували 3 ним особисті стосунки ще в 50-70-роках XX століття. Перелік більшості наукових праць з питань українського мовознавтва зібрано в бібліографії угорської мовознавчої славістики (NYOMÁRKAY 1990) та в бібліографічному покажчику «Закарпатський діалект» (САБАДОШ-МиГОЛинЕць-ПискАч 2009: 27-28).

Ласло Деже народився 26 жовтня 1927 року в селі Буді Будапештської області. Дитячі рокі провів у невеликому містечку Ходмезеввашархель, яке розташоване у південній частині Угорщини. Тут здобув атестат про повну середню освіту. У 1952 році в Будапештському університеті йому було вручено диплом викладача російської, угорської та англійської мов. Того ж року став викладачем Інституту іноземних мов. Після п'яти років роботи в Інституті перейшов працювати до бібліотеки Будапештського університету, де передусім займався питаннями угорського та українського мовознавства. Від 1964 року працював співробітником відділу загального мовознавства Інституту мовознавства Академії наук Угорщини. Окрім української історичної діалектології, серед його наукових зацікавлень - проблеми загального та угорського мовознавства, контрастивної лінгвістики, порівняльної граматики, практичні питання російсько-угорського перекладознавства, методики викладання іноземних мов. На здобуття наукового ступеня «доктор університету» підготував дисертацію на тему старосербсько-хорватського синтаксису 
iз залученням угорсько-сербсько-хорватського матеріалу. Згодом ця праця слугувала основою для видання сербсько-хорватсько-угорської контрастивної граматики. Кандидатську дисертацію на тему «Історія марамороських українських говорів XVI-XVII ст.» захистив у 1956 році. Це був перший етап наукової діяльності Ласло Деже.

Продуктивним виявися і період із 1975 до 1985 року, коли Ласло Деже очолював кафедру загального мовознавства Дебреценського університету ім. Лайоша Кошута і займався переважно проблемами контрастивної лінгвістики та методикою викладання іноземних мов.

У 1988 році науковця запросили в Падуанський університет. У Падуї він проживав до останніх днів свого життя. 3 нагоди сімдесятиріччя колеги та учні присвятили професору Деже збірник наукових праць під назвою «Кӧnyv Dezső Lászlónak» [Книга, присвячена Ласло Деже] (Mıнацоvics 1997).

Ласло Деже - «фахівець із загального мовознавства, славістики та україністики» (ЧучкА 2004: 137). Він $є$ автором більш ніж 200 наукових праць, серед яких 17 монографій (3 - у співавторстві). У шести монографіях порушено проблеми української діалектології: висвітлено історію закарпатських українських говорів (ДэжЕ 1967a), досліджено лексику пам'ятки XVI ст. «Нягівські Повчання» (ДэжЕ 1985), виявлено пам'ятки української ділової писемності XVIII століття (ДэжЕ 1965b), подано матеріали до словника мови закарпатської української літератури XVI-XVII ст. (ДэжЕ 1965a), охарактеризовано угорські запозичення в закарпатських українських писемних пам'ятках XVI-XVIII століть (Dezsö 1989). Як бачимо, не випадково учень Ласло Деже Іштван Удварі назвав його «повноцінним представником угорської україністики» (Удварі у передмові до видання ДэжЕ 1996).

Ласло Деже наголошував на важливості дослідження слов'янських писемних пам'яток, зокрема й українських, зазначив, наскільки потрібною для угорської славістики є лінгвістичний аналіз та публікація мовних пам'яток, серед яких і чимало українських (ДэжЕ 1967a: 7).

Монографія Ласло Деже «Очерки по истории закарпатских говоров» (ДэжЕ 1967a), що складається із двох частин, серед іншого наводить інформацію про історію заселення Закарпаття від XIII до кінця XVIII ст. Автор наголошує, що під час вивчення історії Закарпаття потрібно брати до уваги не тільки історію українського народу, а й історію Угорщини (ДэжЕ 1967а: 21), адже до 1918 року ця територія входила до складу Угорщини, де українці (яких називали рутенами, угрорусами) складали національну меншину. Описуючи розвиток закарпатських українських говорів, учений виділив в історії Закарпаття два періоди: перший охоплює часовий проміжок від XIV до середини XVI ст., другий - від середини XVI до кінця XVIII ст. Українське населення на цій території, на думку Ласло Деже, у першому періоді за походженням можна розподілити на такі групи: 1) давній прошарок українців, предки яких проживали на території Закарпаття ще до XIII ст.; 2) переселенці 3 іншого боку Карпатських гір (найчисельніша група); 3 ) переселенці з більш далеких українських земель (ДэжЕ 1967a: 222). Формування закарпатських 
українських говорів розглянуто в тісному зв'язку з історією становлення закарпатських міст і сіл. Для цього Л. Деже використав відомості української топоніміки та антропоніміки угорських грамот, переписів та урбарів від XIII до кінця XVIII ст. Він уклав карти назв поселень комітатів Берег, Земплин, Мараморош, Угоча та Унг із вказівкою на час першої фіксації поселення, розглянув, наскільки поступово заселялася територія Закарпаття, як змінювалася кількість населення. Для конкордації угорських, російських, словацьких та румунських назв населених пунктів, які фігурують у роботі, у додатках подано список сіл і міст території Закарпаття (ДэжЕ 1967a: 244-292). Словникові статті містять таку інформацію: назва села, яку найчастіше вжито в пам'ятках XVI-XVIII ст., скорочена назва комітату, до якого належало село, назва села російською, українською, словацькою та румунською мовами (якщо вона відома), час заснування села із вказівкою на джерело. Найважливіші варіанти угорських назв поселень подано, навіть якщо немає еквівалентів в інших мовах. «Для встановлення стану української мови XIII-XV ст. можна взяти до уваги й сучасну топонімію, а також угорські запозичення українських пам’яток XVI-XVIII ст.» (ДэжЕ 1967a: 41).

Характеризуючи стан українських говорів від XIV до середини XVI ст., Л. Деже визначає їх фонетичні особливості на підставі угорських грамот, написаних латинкою, мотивуючи це відсутністю виданих українських пам'яток. Дослідник застерігає бути уважними, оцінюючи ці праці, адже грамоти написали угорці, які, можливо, не знали української народної мови або ж, окрім української, знали також словацьку. Тому потрібно брати до уваги i вплив тих говорів, за посередництвом яких автори латиномовних грамот вивчили українську мову (ДэжЕ 1967a: 42). Пояснюючи фонетичні явища топонімів та антропонімів, автор обгрунтовує свої думки, апелюючи до джерел та даних попередніх видань (ДэжЕ 1967a: 41-64, 94-112).

Друга частина монографії містить аналіз мови «Нягівських Повчань на Євангеліє». Деже високо оцінив першу закарпатську пам'ятку середини XVI ст., невідомий автор якої розумів значення народної мови і вважав ії гідною того, щоб писати саме нею (пізніші зауваження свідчать про те, що деякі читачі вважали неправильним таке послідовне використання народної мови в релігійній літературі, як це робив невідомий автор «Повчань»).

«Нягівські Повчання» досліджували А. Петров, В. Ягич, Г. Геровський, Ф. Тихий, однак детальний, різноаспектний лінгвістичний аналіз уперше зробив саме Л. Деже. Аналізуючи мовні явища пам'ятки, він зіставляє їх із даними пам'ятки XVI ст. «Углянський ключ», що є переробкою на південномарамороський говір незакарпатського оригіналу, наводить також відомості для порівняння відповідних частин «Углянського учительського Свангелія» XVII ст., «Сокирницького збірника» початку XVII ст. та інших українських пам'яток незакарпатського походження (Дэже 1967a: 125). На підставі аналізу фонетичних явищ «Нягівських Повчань» Л. Деже дійшов висновку, що «звуковий склад південномарамороського говору з того часу майже не змінився» (ДэжЕ 1967a: 125-128). Морфологічних особливостей виявилося чи- 
мало (ДэжЕ 1967a: 128-159), хоча до часу написання пам'ятки вже сформувалася нова система відмінювання іменників. Він подає парадигму відмінювання усіх типів іменників, а також частоту їх використання. На підставі морфологічних рис науковець припускає, що «Нягівські Повчання» були написані раніше, аніж інші пам'ятки XVII ст., приблизно у другій половині XVI ст. (цього припущення дотримувався й А. Петров на основі аналізу «Повчань»). Порівнюючи морфологічні особливості мови «Нягівських Повчань» 3 даними незакарпатських пам'яток, дослідник виявив, що південномарамороський говір у XVI ст. був більш архаїчним, ніж галицькі та волинські говори (ДэжЕ 1967a: 159). Аналізуючи явища синтаксису (ДэжЕ 1967a: 159-221), автор висловив міркування, що синтаксис «Повчань» не можна ототожнювати із синтаксисом закарпатської народної мови - насамперед тому, що вони $є$ варіантом народної мови «вищого гатунку» (ДэжЕ 1967a: 161).

Словник «Нягівських Повчань» (або, як іiі називає Л. Деже, «Нягівської Постілли») та його аналіз подано в монографії «Украинская лексика середины XVI века: Няговские поучения (Словарь и анализ)» (ДэжЕ 1985). Автор зауважує, що це видання $\epsilon$ варіантом його праці «Материалы к словарю закарпатской украинской литературы XVI-XVII вв.» (ДэжЕ 1965a), надрукованого на мікроплівках, а тому недоступного для більшості читачів (ДэжЕ 1965a: 2). Тут представлено всі слова пам'ятки - усього 2 749. Словникові статті побудовано так: після заголовних слів у дужках подано їх варіанти; граматичну інформацію вказано тільки тоді, якщо необхідно точно визначити частиномовну належність; значення слів викладено російською мовою, наведено також уривки з тексту для ілюстрації та покликання на словники.

До прикладу:

задарь, задаръ 'напрасно, задаром': бою ся, абыхъ / якъ / годь не задаръ трудилъ ся межи вами, 35б. имени Божія задаръ не призываютъ, 229а. - Ср. Чопей, Верхратський I (с. 105-106).

къновати ся 'мучити ся’: такъ ся къновали дяволы и слугы ихъ, коли видятъ, ажъ царствуеть царство Божіе, 103б. - Ср. венг. kín.

помучъ 'помощь': не можетъ намъ хосновати нъчого безъ помоче Божеи, 156а; у неволи нашуй, коли будеме звати Бога у пумучъ, 145a. - Пор.: Українськоросійський словник, И. И. Срезневский: Материалы для словаря древнерусского языка по письменным памятникам I-III. (Graz, 1955-1956), Вол. Розов: Українські грамоти. Т. І. (Київ, 1928), І. Панькевич: Українські говори Підкарпатської Руси і сумежних областей. Ч. І. (Прага, 1938): па ротосуy.

Монографія містить ще такі розділи: про «Нягівську Постіллу» (ДэжЕ 1985: 421-441); статистичне дослідження словотвору (ДэжЕ 1985: 442-481); тематичні групи і гнізда слів (ДэжЕ 1985: 482-507); історичні прошарки лексики (ДэжЕ 1985: 508-513) та словник синонімів (ДэжЕ 1985: 514-522). На жаль, ім'я автора «Постіли» невідоме, однак із тексту повчань можна дізнатися про його погляди на суспільні питання. Автор, за переконанням Ласло Деже, був священиком-кріпаком, сином свого часу, бо в кожній проповіді намагався пояснити євангелійний текст просто і зрозуміло. Щодо релігійних 
питань, то йому імпонували догми православ'я, про «суспільні питання його враження різко відрізнялися від того, що проголошувала верхівка церковної ієрархії» (ДэжЕ 1985: 423). Ласло Деже наводить безліч цитат із пам’ятки, які підтверджують бачення невідомого автора, який став на захист селян, зневажав багатство й багачів, протистояв панам та унії і був вірним ідеям православ' я. Дослідник вважає великою заслугою автора «Постілли» те, що його твори написані мовою народу, що своєю чергою задовольнило не тільки інтереси церкви, а й природні вимоги вірян - слухати проповіді зрозумілою мовою: ито бы тамъ пупь проповъдавъ слово Божее, святое евангеліе, на языкъ, котрыль мовлять люде, итобы могли розумъти убогыи. Што хоснуеть имъ, коли пупь мовить на языку чужому, што они не розумьють (НП 165б). Навіть цитати з Біблії автор перекладає народною мовою, що не було загальноприйнятим у той час. Дослідник встановив, що «одним із головних завдань автора було пояснити притчі Христа, необхідні для розуміння ідейного змісту Біблії» (ДэжЕ 1985: 441). Ласло Деже детально опрацював систему словотвору пам'ятки. Статистичний аналіз словотвору «Постілли» засвідчив, що найпродуктивнішим є суфікс -н-я і його книжна форма -нi-е у віддієслівних іменниках, наприклад: баяня, божъня, воздержаніє, проповъданіе, читаня, бъчелованя, доганяня та ін. Другим щодо частоти вживання є суфікс -ств-о, що слугує для утворення іменників з абстрактним значенням, зокрема: безбоженство, каздувство, неудужество, рождество, убожество тощо. Продуктивними є також суфікси -усть-Ø, -(н)uк-Ø, -(н)-uu-я, -я(-i-e), -ок-Ø,

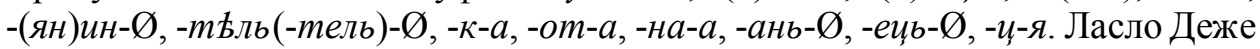
розподілив слова за частотністю, при цьому виявилося, що, окрім деяких службових, найчастіше вживаними є такі повнозначні слова, як: имати, мовити, нашъ, церковъ, братя, пророкъ, свуй, спасти ся, учити, тоть, слово, спасти, члвъкъ, чинити, хрестянинъ, цуарство, божій, сынъ, отецъъ, добрый, небесный, вьровати, правда.

Слова, зафіксовані в «Постіллі», дослідник розподілив у межах восьми тематичних груп: 1) неорганічна природа; 2) органічна природа; 3) сільське господарство; 4) промисловість; 5) транспорт, торгівля; 6) економічні та суспільні відносини, політичні та юридичні установи; 7) повсякденне життя людини; 8) інтелектуальне та емоціональне життя людини: абстрактна та релігійна лексика. ${ }^{1}$ У межах тематичних груп окреслив значну кількість підгруп. Як свідчать результати, найповнішою є тематична група «повсякденне життя людини» (428 одиниць), друга за кількістю група - «інтелектуальне та емоціональне життя людини: абстрактна та релігійна лексика» (184 одиниць). Зазначмо, що 120 одиниць автор зарахував до кількох тематичних груп. Ласло Деже дослідив історичні прошарки словникового складу «Постілли». Зіставивши ії лексику зі словниками давньоруської та сучасної української літературної мов, окреслив такі групи: 1) слова, які вживалися в давньоруській мові й успадковані сучасною українською мовою (найбільша група - 49,3\%

\footnotetext{
${ }^{1}$ Розширений варіант цього розділу подано: ДэжЕ 1965с, яку і використано для аналізу.
} 
слів); 2) слова, які не збереглися в сучасній українській мові, проте відомі російській мові, зокрема возраст, воскресный, вражда, прежде, сласть, соблазнити ся, создание, создати (13,2\%); 3) слова, які у давньоруській мові не вживалися, однак зафіксовані в українській мові XVI століття і в сучасній літературній мові; 4) слова, які не вживалися в давньоруській мові і не зафіксовані в сучасній українській літературній мові (переважно із книжної мови, які не збереглися в сучасній літературній мові).

Загальна лексика української та російської мов складає більш ніж половину всіх слів (53\%), які в давньоруській літературній мові не засвідчені, хоча можна припустити, що частина цих слів функціювала в деяких давньоруських говорах, однак не засвідчена в пам'ятках. До власне української лексики зараховують 47\% слів, із яких понад 9\% слів мають паралелі в польській мові (наприклад, голузя, дяка, жаденъ, задаремный, зычити, картати, мовити, мусити, муць, надаремно, панство, панъ, тежъ, ужиток). 16\% лексики «Постілли» складають церковнослов’ янські елементи, не засвідчені в давньоруській мові, однак вживалися в староукраїнській літературній мові (деякі з них могли походити 3 мови народу або є авторським витвором), а саме: доганяня, извідованя, испомаганя, назнаменовати, приказаня, прятаня, слобожіня та ін. Ласло Деже наводить чимало прикладів східнослов'янської лексики народної мови, не засвідчених словниками, наприклад: айно, бай, бурше, волохъ, вылку, выдсюдъ, выюсурити, дакто, дурнякъ, изверхы, испудъ, лихота, невулнылй, нужъ, окреме, охті, побожити ся, різовати, тверезити ся, указовати ся, хотяй, честовати, чудовати ся. Серед слів іншомовного походження дослідник виділяє гунгаризми, полонізми, румунізми, словакізми та богемізми. Гунгаризмів та полонізмів виявилося найбільше (по 3,3\% від усієї лексики «Постілли»), однак часто виникали труднощі під час встановлення джерела запозичення (чи слово польське, чи спільне для української та польської мов). Запозичення з угорської дослідник зараховує до історичних діалектизмів. Румунізмів, словакізмів та богемізмів засвідчено тільки декілька. Ласло Деже виявив, що 88\% лексики «Постілли» функціювало в народній мові того часу, а близько $12 \%$ складали книжні слова, а також навів приклади слів, які в сучасній українській мові вже не відомі, наприклад, двигань, картань, кортань, окаровань, загадованець, просільникъ, продательникъ, иныли, инуда, увезды, усюгды, опередъ, пузля, умысть , ать, али, ино, хотяй. Значна частина гунгаризмів сьогодні також вийшла з ужитку: бировань, будушловати, вылвалтоват, кедвезовати, німоровшагъ, синте, тамадовати ся. Дослідник засвідчив форми деяких числівників в архаїчній формі: однонадесять, двенадесять, чотыридесять. Такі статистичні відомості показують частку народної мови у словнику пам'ятки. «Наявність живої мови пояснюється тим, що автор свідомо використовував народну мову» (ДэжЕ 1985: 513).

Наприкінці монографії дослідник подає словник синонімів. У синонімні ряди входять слова книжної і народної мови, серед книжних подано церковнослов'янізми (глаголити, казати, речи) чи полонізми (гварити, говорити, 
казати). Серед синонімів - чимало й гунгаризмів: бетъжный, слабый, немуцный; бъчеловати, честовати; инкедливый, послушливый, послушный; марга, иманя, добро, маетность, комора, имъня; фьль, къпъ, образъ // поль.

У бібліографії вміщено список виданих пам'яток середньокарпатського говору, наведено праці, присвячені дослідженню мови цих пам'яток, а також розвідки про історію заселення Закарпаття та розвиток закарпатських українських говорів.

Популярність «Нягівської Постілли» Ласло Деже мотивує тим, що «автор шукає нові шляхи в галузі літературної мови, він не задовольняється шаблоном у поясненні Свангелія, додає свої зауваження, з яких перед нами вимальовується образ гуманно і розумно мислячої людини, яка бореться за культурне піднесення свого народу і співчуває боротьбі свого народу проти панівного пригнічення. Це зробило його твір відомим і в наступних двох століттях, коли історичні умови змінились» (ДэжЕ 1985: 441).

У статті про синтаксичні явища «Нягівських Повчань» (ДЕжЕ 1977b) насамперед зазначено, що «синтаксична система пам'ятки, успадкована від давньоруської мови, розвивалася за внутрішніми закономірностями. Особливості «Повчань», які є частковими, відмінними від особливостей певної частини українських говорів у відповідний час, пояснюються здебільшого архаїчним характером закарпатських говорів» (ДЕжЕ 1977b: 52). Ласло Деже також акцентує на тому, що пам'ятка зберегла синтаксичні явища, які були в давньоруський та староукраїнський період функціювали, проте зникли із розвитком мови. Це почасти можна пояснити тим, що закарпатська мовна територія не була єдиною ні в давньоруську, ні в староукраїнську епоху. Дослідник також наголосив на розвиненості прийменникових конструкцій та підрядних речень порівняно з давньоруською мовою.

Зазначмо те, що повний текст «Нягівських Повчань» було перевидано у 2006 році. Ласло Деже запропонував своєму учневі, видатному угорському русиністові та україністові Іштвану Удварі підготувати до перевидання текст на основі петербурзького видання 1914-1921 років Олексія Петрова (Петровъ 1921). Іштван Удварі здобув за кордоном копію тексту, проте через його передчасну раптову смерть задуми не були реалізовані. Видання здійснив професор Будапештського університету ім. Лоранда Етвеша Андраш Золтан, зауваживши, що «важлива у всіх відношеннях підкарпатська русинська мовна та культурна пам'ятка повинна бути доступною для спеціалістів з історії церкви, для всіх, хто цікавиться процесом становлення русинської літературної мови та культури взагалі» (див. НП Х). До видання Ласло Деже подав інформацію про значення «Нягівських Повчань» для української народномовної писемності того часу, вплив протестантизму, а радше кальвінізму, на погляди автора, значення «Нягівських Повчань» у формуванні румунської народномовної писемності (зважаючи на те, що пам'ятку було перекладено румунською мовою і надруковано 1564 року, що, зокрема, засвідчує їі популярність не лише серед українського, а й серед румунського населення), про стиль автора та порівняльний аспект дослідження пам’яток писемності (ДЕжЕ 1977b). 
Зібравши бібліографію праць Ласло Деже з українського мовознавства та стисло проаналізувавши деякі з них, ми дійшли висновку: учений зробив помітний внесок у розвиток українського мовознавства та історичної діалектології в час, коли основну увагу мовознавці зосереджували на «великих мовах»; результати його досліджень будуть корисними новому поколінню діалектологів, дослідників давніх українських пам'яток. Він одним із перших звернув увагу на важливість вивчення українських писемних пам'яток, які зберігаються в архівах та бібліотеках Угорщини, виявив та дослідив низку цих пам'яток, доклав чималих зусиль, щоб його учні продовжили цю благородну справу.

У пам'яті колег та учнів назавжди збережеться світлий образ щирої людини, визначного науковця і талановитого педагога. Пам’ять про Ласло Деже житиме довго у колі духовних нащадків!

\section{Бібліографія праць Ласло Деже з українського мовознавства}

\section{Монографії}

ДэжЕ $1965 \mathrm{a}=$ ДэжЕ Л. Материаль к словарю закарпатской украинской литературы XVI-XVII вв. Будапешт, 1965.

ДэжЕ $1965 \mathrm{~b}=$ ДэжЕ Л. Памятники украинской деловой письменности ХVIII вв. Будапешт, 1965.

ДэЖЕ 1967a = ДэЖЕ Л. Очерки по истории закарпатских говоров. Budapest, 1967.

ДэЖЕ 1985 = ДэЖЕ Л. Украинская лексика середины XVI века. Няговские поучения. Словарь и анализ. Debrecen, 1985.

ДэжЕ 1996 = ДэЖЕ Л. Деловая письменность русинов в XVII-XVIII веках / A ruszinok hivatalos írásbelisége a XVII-XVIII. században. Под общей редакцией И. Удвари. Nyíregyháza, 1996.

DEZSŐ 1989 = DEZső László: $A$ XVI-XVIII századi kárpátukrán nyelvemlékek magyar jövevényszavai [Угорські запозичення в закарпатських українських писемних пам’ятках XVI-XVIII століть]. (Nyelvtudományi Értekezések 128.) Budapest, 1989.

\section{Cтатті}

ДэжЕ 1957 = ДэЖЕ Л. Урбариальный записи из Мараморошской Верховины. Материалы к исторической диалектологии закарпатских украинских говоров. Studia Slavica Hung. 3 (1957): 235-260.

ДэжЕ 1958 = ДэжЕ Л. К вопросу о венгерских заимствованиях в закарпатских памятниках XVI-XVIII вв. Studia Slavica Hung. 4 (1958): 71-96.

ДэжЕ 1961 = ДэжЕ Л. К вопросу о венгерских заимствованиях в закарпатских памятниках XVI-XVIII вв. Studia Slavica Hung. 7 (1961): 139-176.

ДэжЕ 1962 = ДэжЕ Л. О синтаксисе украинских грамот I (сложноподчиненные предложения). Slavica 2 (1962): 59-83.

ДэжЕ $1965 \mathrm{c}=$ ДэжЕ Л. О лексике закарпатской украинской литературы XVI-XVII вв. Annales Universitatis Scinetiarium Budapestiensis 6 (1965): 117-135. 
ДэжЕ 1965d = ДэжЕ Л. О языке урбариальных записей 1771-1774 гг. Studia Slavica Hung. 11 (1965): 71-93.

ДэжЕ $1966 \mathrm{a}=$ ДэЖЕ Л. Лексика сельского хозяйства и промышленности в закарпатской деловой письменности XVII-XVIII вв. Studia Slavica Hung. 12 (1966): 81-86.

ДэжЕ $1966 \mathrm{~b}=$ ДэжЕ Л. Статистическое исследование словообразования в языковых памятниках. Acta Lingvistica Hung. 16 (1966): 43-52.

ДэжЕ $1967 \mathrm{~b}=$ ДэжЕ Л. О синтаксисе украинских грамот II (сложноподчиненные предложения). Slavica 7 (1967): 3-26.

ДэжЕ 1969a = ДэжЕ Л. Материалы к исторической диалектологии закарпатских говоров. Studia Slavica Hung. 15 (1969): 45-72.

ДэЖЕ $1969 \mathrm{~b}=$ ДэЖЕ Л. Синтаксис простого предложения закарпатских урбариальных записей XVIII вв. В кн.: Науковий збірник Музею украӥнської культури в Свиднику. Т. 4. Кн. 1. Пряшів, 1969. 293-308.

ДэжЕ 1970 = ДэЖЕ Л. Морфология закарпатских урбариальных записей XVIII в. Slavica 10 (1970): 83-98.

ДэжЕ 1974= ДэжЕ Л. Синтаксис сложного предложения урбариальных записей XVIII в. Сложноподчиненные предложения. Slavica 13 (1974): 5-20.

ДэжЕ $1976 \mathrm{a}=$ ДэжЕ Л. Исторические пласты лексики закарпатского украинского языка XVI в. Slavica 14 (1976): 43-60.

ДэжЕ $1976 \mathrm{~b}=$ ДэжЕ Л. Статистическое изучение лексики и грамматики (на историческом материале украинского языка). Acta Lingvistica Hung. 26 (1976): 27-53.

ДЕЖЕ $1977 \mathrm{a}=$ ДЕЖЕ Л. Головні тенденції в розвитку граматичної будови закарпатських говорів XVI-XVIII ст. Мовознавство 1977/3: 41-47.

ДЕжЕ $1977 b=$ ДЕжЕ Л. Синтаксичні явища Нягівських повчань. Мовознавство 1977/4: 52-61.

ДэЖЕ 1979 = ДэжЕ Л. О взглядах и стиле автора закарпатской Няговской Постиллы середины XVI века. Slavica 16 (1979): 5-18.

ДэжЕ 1981 = ДэжЕ Л. О языке украинского полемиста М. Андреллы и закарпатской «народной литературы» XVII в. Studia Slavica Hung. 27 (1981): 19-52.

ДэжЕ 1983 = ДэЖЕ Л. Об историко-типологической характеристике украинской грамматики в сопоставлении с русской и сербско-хорватской. Hungaro-Slavica 1983. Budapest, 1983. 17-40.

ДэжЕ 2006 = ДэжЕ Л. Наговские поучения и их автор. В кн.: Няговские Поучения. Факсимильное воспроизведение текста по изданию А. Л. Петрова с вводной статьей Ласло Дэже. Под редакцией и с предисловием А. Золтана. Nyíregyháza, 2006. XXXV-LV.

Dezső 1958 = Dezső László: Oroszvégesi Mihály müveinek nyelvéről [Про мову творів Михайла Оросвиговсього]. Filológiai közlöny 4 (1958): 336-346.

DEzSÖ 1963 = DEzSÖ László: A kárpátaljai irodalom kezdetei [Початки української літератури]. Filológiai közlöny 9 (1963): 156-161.

DEzső 1966 = Dezső László: A kárpátaljai „népi irodalom” [Закарпатська «народна література»]. Filológiai közlöny 12 (1966): 146-157.

\section{Критика}

ДэжЕ 1986 = ДэЖЕ Л. Украинское языкознание XVI-XVII вв. Slavica 22 (1986): 161177. 


\section{Література}

НП = A nyagovai posztilla / Няговские Поучения. Alekszej Petrov szövegkiadásának fakszimiléje. Dezső László bev. tanulmányával. Szerk. és az előszót írta Zoltán András. / Факсимильное воспроизведение текста по изданию А. Л. Петрова. С вводной статьей Ласло Дэже. Под редакцией и с предисловием А. Золтана. Nyíregyháza, 2006.

ПЕТРОВъ 1921 = ПЕТРОВЪ А. Памятники церковно-религіозной жизни угро-руссовъ XVI-XVII вв. Поучение на Евангеліе по Няговскому списку 1758 г. В кн.: Сборникъ ОтдБленія русскаго языка и словесности Россійской Академіи наукъ. Т. 97. № 2 и посльдній. Петроградъ, 1921. 1-226.

САБАДОШ-МИГОЛИНЕЦЬ-ПИСКАЧ 2009 = САБАДОШ І. В., МИГОЛИНЕЦЬ О. М., ПИСКАЧ О. Д. (ред.) Закарпатський діалект. Бібліографічний покажчик. Ужгород, 2009.

УдВАРі 1996 = УдВАРИ И. Előszó [Передмова]. В кн.: ДэжЁ Ласло: Деловая письменность русинов в XVII-XVIII веках / A ruszinok hivatalos írásbelisége a XVII-XVIII. században. Под общей редакцией И. Удвари. Nyíregyháza, 1996. 3.

ЧучкА 2004 = ЧучкА П. П. Деже Ласло. В кн.: Українська мова. Енциклопедія. Київ, 2004. 133.

Miнalovics 1997 = Miнalovics Árpád (szerk.): Könyv Dezső Lászlónak [Книга Ласло Деже]. Nyíregyháza, 1997.

NYOMÁRKAY 1990 = NYOMÁRKAY István et al. (szerk.) A magyarországi szláv nyelvtudomány bibliográfiája 1985-ig / Библиография венгерской языковедческой науки до 1985 2. Budapest, 1990. 